\section{Anticorpos antifosfolipídios: novos critérios}

\author{
José M.P. Godoy \\ Moacir F. Godoy \\ Domingo M. Braile
}

Departamento de Cardiologia e Cirurgia

Cardiovascular da Faculdade de Medicina de São

José do Rio Preto - FAMERP, SP

\section{Sr. Editor,}

A abordagem deste tema tem como objetivo alertar sobre a importância dos anticorpos antifosfolipídios no contexto da hematologia.

A descrição da síndrome antifosfolipídica em 1985 (1) constituiu em um dos mais interessantes relatos clínicolaboratoriais da hematologia nos últimos anos (2).

O papel patogênico e o mecanismo de ação destes anticorpos permanecem controversos. Entretanto, a interferência nos principais componentes do sistema de coagulação é postulada como os prováveis mecanismos trombogênicos da síndrome (2).

A trombose representa uma das principais complicações destes anticorpos, porém várias associações com diversos quadros clínicos têm sido relatadas (3-5). A arteriosclerose é uma delas e cria novas expectativas em relação ao assunto (6). A identificação em pessoas saudáveis como em doadores de banco de sangue desperta a curiosidade sobre as possíveis interferências nos receptores desse sangue (7).

Os critérios diagnósticos foram estabelecidos inicialmente por Hugles et. al. em 1986, onde a presença de trombose arterial e/ou venosa, aborto de repetição e trombocitopenia associada à positividade para os anticorpos anticardiolipina e/ou anticoagulante lúpico constituem a síndrome (1). Somente a positividade destes anticorpos não constitui na síndrome, porém, em sinal de alerta para eventual quadro trombótico.

Em 1989 foi proposto por Alarcón-Segovia et al a inclusão do livedo reticularis, úlceras de membros inferiores e anemia hemolítica nos critérios clínicos que foram previamente estabelecidos por Hugles (8).

Novas modificações nos critérios clínicos de diagnóstico surgiram em 1999 durante o simpósio sobre estes anticorpos, onde foi sugerido que a síndrome passaria a constar do quadro trombótico e de morbidade gestacional associado a positividade para estes anticorpos. Foi sugerida a investigação laboratorial dos anticorpos anticardiolipina (IgG e IgM) e do anticoagulante lúpico (9).
A exclusão da trombocitopenia, que era um dos três critérios clínicos iniciais propostos por Hugles em 1986 para a síndrome, e dos três critérios proposto por Alarcón-Segóvia em 1989: anemia hemolítica, úlcera de perna e livedo reticularis, restringiu o diagnóstico da síndrome.

As modificações destes critérios trazem questionamento sobre estas alterações. Um exemplo é o caso da IgA anticardiolipina e, especificamente nos casos onde ela está associada com quadro trombótico ou gestacional que deixa de constituir na síndrome (10).

Em relação ao tratamento, a anticoagulação é a opção terapêutica de escolha, entretanto, não se tem um consenso sobre os seus níveis de manutenção da relação normatizada internacional (RNI). Uma das sugestões é manter o RNI entre 3 a 4 , o que pode representar maior risco de sangramento.

A heparina, os anticoagulantes orais e os antiagregantes plaquetários são as principais substâncias empregadas no tratamento e na prevenção dos novos quadros trombóticos. Se a associação delas pode ocorrer, entretanto, não se tem um consenso. Outro questionamento é sobre o tempo de manutenção da anticoagulação, onde talvez uma abordagem individualizada para cada caso seja recomendada. Os riscos e os benefícios da anticoagulação devem ser avaliados sempre que o paciente for exposto a novos riscos.

A plaquetopenia que fazia parte da síndrome clássica e que foi eliminada no consenso em 1999 é abordada pelos hematologistas de acordo com o quadro clínico individualizado.

$\mathrm{Na}$ prevenção dos abortos de repetição associados aos antifosfolipídios, a anticoagulação e os antiagregantes plaquetários são drogas usualmente empregadas. Os corticóides e os imunossupressores podem ser considerados em pacientes que estão na fase ativa de uma colagenose.

Não surgiram até o momento drogas específicas para a redução dos níveis destes anticorpos. Os corticóides e imunossupressores falharam em promover esta redução e, portanto, indicados em casos selecionados.

A investigação destes anticorpos faz-se necessária nos pacientes que desenvolvem um quadro trombótico ou que tenham aborto de repetição. Assim, poderemos elucidar estes diagnósticos bem como abrir caminho para maior compreensão sobre eles. As perspectivas de chegar ao consenso sobre o papel patogênico e o mecanismo de ação deles permanecem controversas. Estes dados vêm reforçar a necessidade de novas pesquisas.

Uma das associações que tem chamado atenção é com relação a arteriosclerose, onde vários estudos têm 
demonstrado que estes anticorpos constituem num fator de risco (6). Constatamos associação dos anticorpos anticardiolipina nos pacientes com claudicação intermitente, estudo em fase de publicação. Os níveis destes anticorpos e a importância deles no desenvolvimento da síndrome também são controversos. Detectamos que os níveis intermediários estão associados com os quadro de trombose arterial e venosa $(11,12)$.

Entretanto, a retrombose venosa foi associada somente nos casos de pacientes com altos títulos, estudo em fase de publicação. Não verificamos associação com a trombocitopenia, entretanto foi observado nos pacientes com úlceras crônicas em membros inferiores (3).

Em relação às mudanças de critérios clínicos diagnósticos, questionamos nos casos de úlceras crônicas de membros inferiores e quanto aos IgA anticardiolpina.

Sugerimos maior ênfase na investigação desta síndrome e atenção em relação às mudanças nos critérios diagnósticos.

\section{Antiphospholipid antibody: new criteria} José M.P. Godoy, Moacir F. Godoy, Domingo M. Braile

\begin{abstract}
Suggested modifications of the clinical diagnostic criteria of antiphospholipid antibody syndrome and therapeutic approaches are related in this letter.
\end{abstract}

\section{Referências Bibliográficas}

1. Hugles G.V.R., Harris E.N., Gharavi A.R. The anticardiolipin syndrome. J Rheumatol 1986; 13: 486-9.

2. Staub H.C. Detecção de anticorpos antifosfolipidios: observações práticas. Rev.Bras. Reumatol 1995; 35: 285-9.

3. Godoy J.M.P., Godoy M.F., Parma A.H.C. Anticuerpos Anticardiolipina y Ulceras de los Miembros Inferiores. Patologia Vascular 1999; V:39-42.

4. Godoy J.M.P., Godoy M.F., Braile D.M., Batigália F. Tromboflebite superficial de repetição e anticorpos anticardiolipina. Angiology 2001; 52:127-9.
5. Godoy J.M.P., Godoy M.F., Reis L.F., Rincon O.Y.P. Anticuerpo Anticardiolipina y enfermedad de Buerguer Rev Panamericana de Flebologia y Linfologia 1999; 35:34-6.

6. Matsura E., Kobayashi K., Yassuda T., Koike T. Antiphospholipid antibodies and atherosclerosis Lupus 1998; 7(2)s:135-9.

7. Godoy J.M.P., Lúpino P.L., Souza D.R.S., Parma A.H.C., Angulo I.L., Godoy M.F. Prevalência de Anticorpos Anticardiolipina em doadores voluntários de banco de sangue. Bol Soc Bras Hematol Hemot, 1998; 20 (178):65-8.

8. Alarcón-Segovia D., Delezé M., Oria M. et al: Antiphospholipid antibodies and the antiphospholipid syndrome in systemic lupus erythematosus. A prospective analysis of 500 consecutive patients. Medicine 1989; 68:353-65.

9. Wendell A.W., Ghavari A.E., Koike T., et al: Internacional consensus statement on preliminary classification for difinitive antiphospholipid syndrome. Arthritis Rheum 1999; 42:1309-11.

10. Dahmer R., Staub H.L. Sindrome antifosfolipídica: os dilemas dos novos critérios. Rev Bras Reumatol 2001; 41(1):59-61.

11. Godoy J.M.P. Prevalência de anticorpo anticardiolipina na trombose periférica. Trabalho apresentado para obtenção de título de mestrado. FAMERP 1997.

12. Godoy J.M.P., Braile D.M., Torres C.A.A., Godoy M.F. Prevalence of Anticardiolipin Antibodies in Peripheral Arterial Thrombosis. Angiology 2000; 51 : 473-477.

Recebido: 05/06/01

Aceito: 25/07/01

Correspondência: José Maria Pereira Godoy

Rua Floriano Peixoto, 295. 15010-020.

São José do Rio Preto- SP

Fone: (17) 233-1087. E-mail: godoyjmp@riopreto.com.br 